Marta Zambrzycka

DOI $10.15290 / \mathrm{sw} .2017 .17 .09$

Uniwersytet Warszawski

Wydział Lingwistyki Stosowanej

Katedra Ukrainistyki

tel. 600761652

e-mail: marta-zambrzycka@wp.pl

\title{
Koncepcja ukraińskiej kultury ,miedzy Wschodem a Zachodem" w monografiach literaturoznawczych dotyczących prozy Wałerija Szewczuka
}

Słowa kluczowe: Wschód, Zachód, synteza, literaturoznawstwo, ukraińska tożsamość

\section{Wstęp}

W artykule analizuję w jaki sposób mająca dość długą tradycję narracja, sytuująca ukraińską kulturę pomiędzy dwoma wyobrażonymi formacjami kulturowymi Wschodu i Zachodu znajduje odzwierciedlenie we współczesnych tekstach literaturoznawczych, na przykładzie trzech monografii naukowych dotyczących twórczości Wałerija Szewczuka. Koncentruję się na trzech ukraińskojęzycznych monografiach, których narracja w dużym stopniu wpisuje się w koncepcję ukraińskiej kultury jako znajdującej się „pomiędzy", gdyż ich autorzy definiują twórczość Wałerija Szewczuka jako syntezę elementów rodzimych, wywodzących się z ukraińskiej tradycji i folkloru oraz nurtów i tendencji literatury zachodniej (europejskiej i amerykańskiej). Owe monografie to: książka Ludmiły Tarnaszyńskiej (Людмила Тарнашинська) Художня галактика Валерія Шевчука Київ 2001, praca Anny Horniatko-Szumyłowycz (Анна Горнятко-Шумилович), Проза Валерія Шевчука традийійе і новаторське, Szczecin, 2001, oraz Natalii Horodniuk (Наталія Городднюк) Знаки необарокової культури Валерія Шевчука: компаративні аспекти, Київ, 2006. Ze wszystkich wymienionych mono- 
grafii wyłania się całościowy obraz twórczości Wałerija Szewczuka jako syntezy elementów zachodnich i rodzimych (wschodnich?) tradycyjnych i nowatorskich.

\section{Ukraina między Wschodem i Zachodem}

Opis kondycji ukraińskiej kultury jako znajdującej się między wpływami Wschodu i Zachodu, a co za tym idzie, będącej syntezą dwóch tradycji ma dość długą historię. Natalia Jakowenko pisze, że w ukraińskiej myśli humanistycznej po raz pierwszy koncepcję tę sformułował Wacław Lipinski w 1925 roku, w eseju Religia i Kościót w dziejach Ukrainy. [Jakowenko 2010, 378] Lipiński podkreślał, iż położenie Ukrainy na styku świata bizantyjskiego i rzymskiego stanowi jedną z przyczyn problemów z ukraińską państwowością i tożsamością. [Jakowenko 2010, 379] Istotne jest, że terytorium Ukrainy w świadomości społeczeństw zachodnich dość wcześnie zostało utożsamione ze wschodem (w dużym stopniu z racji przynależności religijnej). Jak pisze Ihor Szewczenko, stało się to jeszcze przed pierwszym rozbiorem Polski. [Szewczenko 1996, 11] Jednak największy wpływ na definiowanie Ukrainy jako „Wschodu” wywarł okres XVIII-XIX wieku oraz historia najnowsza, zwłaszcza długotrwała przynależności do bloku państw socjalistycznych i doświadczenie komunizmu. Ta „wschodnia” przynależność ziem ukraińskich była niejednokrotnie podważana i kwestionowana przez lokalne elity, dążące do wykazania związków własnej kultury ze światem wartości zachodnich. Prozachodnia orientacja Ukrainy stanowiła niepodważalny „dogmat” Rozstrzelanego Odrodzenia, zawarty między innymi w pracach wybitnego historyka Mychajła Hruszewskiego. Jak podkreśla Mykoła Riabczuk, idea powrotu do Europy była przez Hruszewskiego rozumiana jako: „przywrócenie naturalnego stanu rzeczy, jako naprawa historycznych błędów i niesprawiedliwości (...) tego rodzaju (...) stosunek do Zachodu wynikał z całej historii rozwoju ukraińskiej tożsamości narodowej, która od chwili swych narodzin w pierwszej połowie XIX wieku zmuszona była akcentować ukraińską odrębność wobec Rosji." [Riabczuk 2004, 34]

Ukraińska myśl humanistyczna zarówno w pierwszych dziesięcioleciach XX wieku jak i współcześnie wykazywała i wykazuje skłonność do odrzucania tego co kojarzone ze „wschodniością”. Ihor Szewczenko, podkreśla, że odrzucanie „Wschodu” jest „wyrazem postawy współczesnych wschodnioeuropejskich warstw wykształconych", a w każdym razie ich większości. [Szewczenko 1996, 9] Natalia Jakowenko zauważa z kolei, iż „silny zachod- 
ni akcent, wyszukiwanie w historii i kulturze Ukrainy wyłącznie elementów pokrewieństwa z Europą" [Jakowenko 2010, 383] ukształtował się już w pierwszych dziesięcioleciach XX wieku, kreując obraz Ukrainy zwróconej - zgodnie ze słowami Dmytra Czyżewskiego „twarzą ku Europie” [Jakowenko 2010, 383]. Ta tendencja wydaje się żywa do dziś.

Ze względu na złożoną sytuację geopolityczną i kulturową niepodległej Ukrainy, a także na wciąż aktualne dyskusje dotyczące tożsamości, ukraińscy humaniści wiele miejsca poświęcają analizie związków kulturowych między Ukrainą a Europą Zachodnią. Kwestia tożsamości ukraińskiej była szczególnie intensywnie dyskutowana w latach dziewięćdziesiątych, lecz do dziś pozostaje niezwykle ważna. Jak pisze Ola Hnatiuk w książce Pożegnanie z imperium. Ukraińskie dyskusje o tożsamości:

Otwarcie na świat jakie nastąpiło po upadku Związku Radzieckiego, pośród licznych innych skutków przyniosło także konfrontację ze światem zewnętrznym, (...) uobecniając układ odniesienia - kulturę europejską a także amerykańską. (...) Modernizacyjne wyzwanie stwarza bowiem konieczność ponownego samookreślenia, przekształcenia tożsamości”. [Hnatiuk 2003, 14]

W owej dyskusji szczególne miejsce zajmuje konstrukcja pojęciowa „Europy Zachodniej" i kulturowej do niej przynależności. Jak zauważa Jarosław Hrycak, o współoddziaływaniu wpływów wschodnich i zachodnich na ukraińską kulturę napisano już wiele, widoczny jest swoisty nacisk, jaki badacze wciąż kładą na europejski wymiar tożsamości ukraińskiej, wartościując go zdecydowanie pozytywnie. [Hrycak 2009, 212]

Znaczenie nadawane „europejskości” ukraińskiej kultury jest widoczne również we współczesnym literaturoznawstwie. W dalszej części tekstu skoncentruję się na narracjach trzech badaczy twórczości Wałerija Szewczuka, dla których zachodnioeuropejski wymiar prozy tego autora wydaje się szczególnie istotny. Lidmiła Tarnaszyńska, Anna Horniatko-Szumyłowycz oraz Natalia Horodniuk zwracają uwage na wpływy i wzorce, łączące prozę Szewczuka z autorami literatury światowej. Podkreślają jednocześnie, iż wpływy i wzorce czerpane z zachodniej literatury nie stanowią naśladownictwa, lecz poprzez syntezę z tradycją rodzimą, wyraźnie obecną w prozie Szewczuka łączą się w nowa, oryginalną jakość literacką. Moim celem nie jest kwestionowanie ustaleń wymienionych badaczy, chcę jedynie zwrócić uwage na fakt, iż prezentowana przez nich analiza literaturoznawcza wpisuje się w narrację definiującą kulturę ukraińską jako syntezę oddziaływań kulturowych, przy czym istotne miejsce zajmuje - zwłaszcza w monografii Ludmiły Tarnaszyńskiej dążenie do wykazania „europeizmu” ukraińskiej literatury. 


\section{Wałerij Szewczuk i ,zachodnia" tradycja literacka}

Wpływy literatury światowej na twórczość Szewczuka analizowało wielu ukraińskich literaturoznawców. Natałka Bilocerkiweć bada podobieństwa między powieściami Oko otchłani i Imię Róźy. [Білоцерківець 1997, 188-189] Larysa Zaleska-Onyszkewycz wskazuje pojawiające się w powieści Птахи з невидомого острова paralele z opisem Piekta w Boskiej komedii Dante Alighieri. [Залеська-Онишкевич 1996, 93-96] Wielu autorów zwracało też uwagę na inspiracje egzystencjalizmem porównując powieść Mor z Dżuma Alberta Camus'a. Anna Berehulak znajduje w powieści Dom na wzgórzu wpływy iberoamerykańskiego realizmu magicznego, zwłaszcza zaś twórczości Gabriela Garcii Marqueza i Izabel Allande. [Бepeгуляк 1993, 67-75]

Analiza twórczości Szewczuka w kontekście literatury europejskiej i amerykańskiej stanowi jeden z głównych problemów monografii Ludmiły Tarnaszyńskiej Художня галактика Валерія Шевчука. Poszukując paraleli między powieściami ukraińskiego autora i wybitnych przedstawicieli literatury światowej, takich jak: William Faulkner, Thomas Mann, Knut Hamsun, William Golding czy Ernest Hemingway, badaczka stara się udowodnić, iż literaturę ukraińską należy analizować, jako składową spuścizny europejskiej, opartą na wspólnym systemie wartości i tradycji literacko-filozoficznej oraz na zbliżonym doświadczeniu historycznym. Kwestia relacji kulturowych między Ukrainą i Europą Zachodnią oraz „europejskości" literatury ukraińskiej stanowiła problem, poruszany już w pierwszych dziesięcioleciach XX wieku przez ukraińskiego literaturoznawcę Dymytra Czyżewskiego. Wiązało się to z rozwijającym się w latach dwudziestych ruchem kulturalnym (tzw. „Rozstrzelanym Odrodzeniem”), którego jednym z postulatów było włączenie Ukrainy w szeroki kontekst europejskich nurtów artystycznych i literackich. Dmytro Czyżewski podkreślał, iż literatura ukraińska tyle ulega wpływom europejskim, nie tyle „europeizuje się”, co po prostu przynależy do szeroko rozumianego europejskiego kręgu kulturowego, będąc jego immanentną składową. Badacz stwierdza:

Український культурний розвиток мусимо визнати складовим елементом загальноевропейського, українську культуру елементом европейськой цілості, коли український культурний розвиток проходив ці самі стадії, що й европейський взагалі, то не тому, що на Україну приходили ззовні впливи, не тому, що на Україні чинять (...) фактори чужого походження, а тому, що Україна, яко частинка европейської культурної цілості переживає ті самі внутрішні процеси, що й цілість, до якої вона належить. [Чижевський 1956, 271] 
Ludmiła Tarnaszyńska formułuje bardzo podobną myśl. Posługując się terminem „europeizmu” w literaturze zauważa, iż ów „europeizm” nie stanowi teoretycznej konstrukcji, mającej na celu uczynienie kultury czy literatury ukraińskiej „bardziej europejską”, lecz jest obiektywną kategorią, wypływającą z kulturowo-historycznej przynależności Ukrainy do kręgu wartości i przekonań wypracowanych przez kulturę europejską:

Виходитимемо з того, що европейскість - це все-таки не вигадана штучна, теоретична конструкція а категорія, об'єктивно явлена нам історіею як у геополітичних так і соціокультурних, духових вимірах. (...) включає вона в себе як філософські, естетичні, етичні, психологічні параметри, так і форми зв'язку художнього слова з реальністью, адекватні часові й сприйнятю їх реципієнтами - незалежно від їх національної приналежності (...). [Тарнашинська 2001, 30]

Zdaniem autorki „europeizm” stanowić ma nieodłączną i naturalną cechę literatury i kultury ukraińskiej a liczne odwołania do wartości rodzimych, rdzennie ukraińskich nie stanowią jego zaprzeczenia. Właśnie te dwa elementy: kultura rodzima, odwołująca się do kanonu mitologiczno-folklorystycznych symboli i tradycji ukraińskiego baroku oraz nawiązanie do nurtów estetyczno-filozoficznych Europy zachodniej decydują, według Tarnaszyńskiej o oryginalności prozy Walerija Szewczuka, którego twórczość określa jako syntezę rodzimego i ogólnoeuropejskiego, tradycyjnego i nowatorskiego. [Тарнашинська 2001, 34]

Rekapitulując wywód autorki monografii Художня галактика $B a$ лерія Шевчука, stwierdzamy, iż związki z zachodnioeuropejskimi prądami literackimi realizują się w twórczości Szewczuka zarówno na poziomie struktur fabularnych jak i w warstwie rozwiązań formalnych. A więc zarówno konstrukcja bohatera i jego losów, jak również metody opisu rzeczywistości przedstawionej są, zdaniem Tarnaszyńskiej w pewnym stopniu zdeterminowane zachodnioeuropejskimi inspiracjami autora. Badaczka podkreśla, iż tych wpływów nie należy rozumieć w kategoriach zapożyczenia, odwzorowania, czerpania gotowych wzorów, lecz raczej jako rodzaj inspiracji twórczej, podobnej poetyki, wynikającej raczej z wrażliwości twórcy niż z tendencji do naśladownictwa. Tarnaszyńska podkreśla również, iż twórczość Walerija Szewczuka wpisuje się częściowo w typowe dla pokolenia pisarzy lat sześćdziesiątych dążenie do modernizacji ukraińskiej literatury poprzez czerpanie inspiracji z dorobku nurtów i tendencji dominujących w literaturach zachodnioeuropejskich. Cytując ponownie autorkę: „шістдесятники (...) це другий (...) після розстріланого Відродження (...) потужний прорив у ХХ столітті в духовий простір Європи” [Тарнашинська 2001, 29-30] 


\section{Wałerij Szewczuk i „zachodnia” tradycja filozoficzna}

Drugim źródłem inspiracji twórczych, na które zwracają uwagę badacze prozy Szewczuka jest tradycja rodzima. Jego proza pozostaje głęboko zanurzona w historii ukraińskiego piśmiennictwa, zwłaszcza zaś w filozofii i estetyce ukraińskiego baroku. Wyraźne są też inspiracje myślą XVIII-wiecznego filozofa Hryhorija Skoworody i XIX-wieczą koncepcją korodcentryzmu Pamfiła Jurkiewicza. Szewczuk czerpie też inspiracje ze słowiańskiego folkloru i mitologii. Jego twórczość jest jednocześnie uniwersalna i na wskroś ukraińska, nierozerwalnie związana z przeszłością i współczesnością Ukrainy, z jej tradycją, historią, mentalnością, poczuciem estetyki, swoistym rozumieniem człowieka i jego miejsca w świecie. O twórczości Szewczuka jako o syntezie rodzimego i ogólnoświatowego artystyczno-filozoficznego doświadczenia pisze Anna Horniatko-Szumyłowycz w pracy Проза Валерія Шевчука традийійне і новаторське:

Творчі досягнення В. Шевчука можна розглядати саме як результат двох чинників. Один із них - уважне ставлення до (...) національних джерел і традицій. Другий же чинник - подолання національної замкненості і сміливе прилучення до прогресивного світового ідейно-художнього досвіду. [Горнятко-Шумилович 2001, 17]

Zdaniem badaczki, czerpiąc z tradycji literatury i kultury światowej, Szewczuk dokonuje swego rodzaju przetworzenia motywów; wpisując to co uniwersalne w kontekst lokalny stwarza nową kulturowo-estetyczną jakość. Widać to wyraźnie na przykładzie wykorzystanych przez niego koncepcji zachodnioeuropejskiego egzystencjalizmu ${ }^{1}$. Badając wpływy egzystencjalizmu na twórczość Szewczuka Anna Horniatko-Szumyłowycz stwierdza istnienie wyraźnych paraleli między prozą ukraińskiego pisarza a dziełami Alberta Camus'a czy Jeana Paula Sartre'a, podkreśla jednocześnie, iż twórczości Szewczuka nie można uznać za pełny wyraz filozofii egzystencjalizmu, jako, że autor nie stara się realizować założeń nurtu, lecz jedynie czerpie określone motywy, stawiając własną diagnozę kondycji ludzkiej. [Горнятко-Шумилович 2001, 84] Te motywy to przede wszystkim: bohater jako jednostka, niepowtarzalna indywidualność oraz analiza jego wewnętrznego, subiektywnego postrzegania rzeczywistości. Właśnie nacisk, położony na analize psychiki bohatera, przeniesienie punktu ciężkości ze „świata zewnętrznego", „do wewnątrz”, w głąb świadomości bohatera i uczynienie z jego

1 O egzystencjalizmie we wczesnej prozie Szewczuka: Marta Zambrzycka, Egzystencjalizm we wczesnej prozie Waterija Szewczuka, „Przegląd Wschodnioeuropejski”, tom V, 2014 (2), s. 171-183. 
moralnych rozterek podstawowej osi fabularnej jest cechą charakterystyczną twórczości ukraińskiego pisarza. Podobny zabieg obserwujemy w twórczości Jeana Paula Sartre'a, który swych bohaterów przedstawia nie tyle jako ludzi istniejących i funkcjonujących w społeczeństwie co przede wszystkim jako jednostki skonfliktowane wewnętrznie, bezustannie analizujące swą kondycję egzystencjalną, i pragnące „autentycznego życia”. [Franczak 2002, 43] O tym podobieństwie w przedstawieniach bohatera pisze Anna Horniatko-Szumyłowycz:

Сартр бачив людську діяльність лише в праці свідомості, натомість політична і соціальна активність людини була виключена із сфери філософського аналізу, бо він не вважав їх повністью людськими (...) персонажів Шевчукових творів неодноразово звинувачували в асоціальності, відреченні від суспільного тла. [Горнятко-Шумилович 2001, 95]

Oprócz wspomnianego przez badaczkę oderwania bohaterów od kontekstu społecznego, w prozie Szewczuka pojawiają się też motywy obojętności, martwoty duchowej, charakterystyczne dla pisarzy nurtu egzystencjalizmu. Dotyczy to zwłaszcza jego wczesnych utworów, ukazujących w konwencji realizmu Ukrainę lat powojennych. A więc: Nabrzeżna 12, Стежка в травi, Гість удома сzу Голуби над дзвіничею, - to dzieła, w których dominujące jest poczucie pustki, absurdu i morderczej monotonii życia. Porównując powieść Szewczuka Nabrzeżna 12 oraz utwór Mdłości Jeana Paula Sartre'a, Ludmiła Tarnaszyńska odnajduje liczne paralele w postawie życiowej bohaterów. Autorka podkreśla, iż obaj pisarze starają się ukazać wywołany poczuciem absurdu stan duchowego zobojętnienia:

Герой Набережної 12 Валерія Шевчука, як і Сартрівський герой з роману Нудота, переживає такеж відчуття нудоти - як реакції свідомості на абсурдність світу. Цей світ із його жорстокими законами буття - це те вбивче середовище, у якому живуть Шевчукові герої і вчинки яких, відповідно, мусять набирати такої ж алогічної мотивації. [Тарнашинська 2001, 133]

Można stwierdzić, że charakterystyka życiowej kondycji bohaterów Walerija Szewczuka w dużym stopniu odpowiada sformułowanej przez „filozofów egzystencji” diagnozie sytuacji człowieka w świecie. Zdaniem cytowanych autorek Szewczuk wykracza jednak daleko poza ponurą diagnoze egzystencji jako kategorii bezsensownej i tragicznej, a przełamanie głoszonej przez zachodnioeuropejskich filozofów apatii i bezsensu widzi w zwrocie do „filozofii serca” i poszukiwania prawdy we własnym wnętrzu. Zarówno Tarnaszyńska jak i Horniatko-Szumyłowycz podkreślają, iż wypracowana 
przez niego wersja egzystencjalizmu jest filozofią optymistyczną, zakładającą istnienie ładu i harmonii oraz dającą możliwość poszukiwania prawdziwej mądrości i dobra. Horniatko-Szumyłowycz odnajduje źródła „pozytywnego egzystencjalizmu" w sformułowanej przez Hryhorija Skoworodę koncepcji szczęścia i prawdy:

позитивний екзистенціалізм характерний для української літератури від Т. Шевченка до Т. Осмачки, джерелом якого є традиціїна українська концепція щастя, що ії висунув у XVIII ст. Г. Сковорода. [Горнятко-Шумилович 2001, 114]

Również Tarnaszyńska podkreśla zasadniczą odmienność egzystencjalizmu Szewczuka od poglądów zachodnioeuropejskich egzystencjalistów. Autorka twierdzi, iż ukraińskiego autora charakteryzuje przezwyciężenie charakterystycznego dla Sartre'a ateizmu, samotności i lęku Kierkegaarda, czy właściwego dla twórczości Alberta Camus'a poczucia pustki i beznadziei:

Розглядаючи приналежність Валерія Шевчука до письменників-екзистенціалістів, (...) маємо всі підстави твердити, що (...) Валерій Шевчук вніс до нього і свої помітні, художньо-естетичні напрацювання. Насамперед письменник засадничо досліджує стан екзистенційної свідомості, яка попри все долає абсурд, керуючись сковородинівським копай криницю всередині себе або збудуй себе, грунтуючись переважно на марселівському екзистенціалі надії, побиваючи цим камюнівську безнадійність, кіркегорівську (...) самотність. [Тарнашинська 2001, 189]

Przedstawiając twórczość pisarza w kontekście filozofii egzystencjalizmu obie cytowane wyżej badaczki odwołują się do pojęć „,syntezy” czy „połączenia" myśli zachodnioeuropejskiej z tradycją rodzimą, silnie związaną ze wschodniosłowiańskim kręgiem kulturowym. Nazwiska Sartre'a i Hryhorija Skoworody pojawiają się tu na równych prawach, jako dwa czynniki, które niezależnie od różnicy epok, poglądów, kulturowego i religijnego kontekstu tworzą nową, oryginalną - można powiedzieć „,szewczukowską” wersję egzystencjalizmu. Wersję będąca połączeniem XVIII-wiecznej tradycji wschodnioeuropejskiej, prawosławnej filozofii z zachodnioeuropejską myślą filozoficzną XX wieku. Szewczuk niewątpliwie odwołuje się w swojej prozie (zwłaszcza wczesnej) do najogólniej rozumianych założeń egzystencjalizmu, niewątpliwie też tradycja filozoficzna wywodząca się od Skoworody jest mu bardzo bliska, zastanawia jednak połączenie przez badaczki jego twórczości tych dwóch elementów w jedną całość filozoficzno-moralną. Wydaje się, iż podstawą tego połączenia jest nie tyle obraz świata wyłaniający się z kart powieści Szewczuka, co utrwalona w ukraińskiej humanistyce tradycja myślenia o rodzimej kulturze jako syntezie wpływów. 


\section{Szewczuk i postmodernizm - ukraiński barok i postmodernistyczny neobarok}

Ostatnią monografią, do której odwołam się próbując ukazać funkcjonowanie koncepcji „Ukrainy między Wschodem a Zachodem” we współczesnych ukraińskich badaniach literaturoznawczych jest książka Natalii Horodniuk, Знаки необарокової культури Валерія Шевчука: компаративнi аспекти. Odwołując się do założeń semiotyki kultury autorka analizuje postmodernistyczne strategie narracyjne, realizowane w ramach twórczości Walerija Szewczuka w formie neobarokowej poetyki „tekstu kultury.” [Городнюк 2006, 8/9] Zastosowana przez badaczkę metoda komparatystyczna, pozwala na porównanie twórczości ukraińskiego pisarza z dziełami najważniejszych przedstawicieli światowego postmodernizmu, takich jak Umberto Eco, Jorge Luis Borges czy Milorad Pavić. [Городнюк 2006, 7] Autorka definiuje poetykę neobaroku jako jedną z podstawowych strategii postmodernistycznego obrazowania, co umożliwia jej wpisanie twórczości Szewczuka w kontekst zachodnioeuropejskiej literatury ponowoczesnej. Jednocześnie Horodniuk podkreśla, iż wykorzystane przez Szewczuka symbole funkcjonują w odmiennym od zachodnioeuropejskiego kontekście i przynależą tym samym do prawosławnego kręgu światopoglądowego. Badaczka lokuje więc twórczość Szewczuka „pomiędzy” literackimi strategiami zachodniego postmodernizmu a tradycją filozoficzno-estetyczną wschodniej słowiańszczyzny.

Horodniuk nawiązuje do semiotycznej interpretacji kultury jako systemu znaków oraz sformułowanej przez Jurija Łotmana teorii dzieła literackiego jako jednego z „wtórnych systemów modelujących”, charakteryzujących się znakowością. Swobodne operowanie symbolami, poetyka cytatu i zapożyczenia, liczne odwołania do tekstów poprzedników, oraz strategia parafrazy a także swoista palimpsestowość (nakładanie się znaczeń, tradycji i odnośników literacko-kulturowych) sprawiają, że prozę Szewczuka należy, zdaniem badaczki, rozpatrywać w semiotycznym kontekście „tekstu kultury”, i wpisać w nurt prozy postmodernistycznej. Horodniuk pisze:

Серед визначальних рис поетики В. Шевчука, що дозволяють віднести його художню творчість до прози культури (...) акцентуємо увагу на таких: вільне оперування знаками культури, установка на текст (у структкрно-семіотичному розумінні - будь-яке культурно значуще повідомлення) як вищу реальність (світ як текст), поетика палімпсесту, необароковість як постмодерна стратегія культуротворення (...). [Городнюк 2006, 8/9] 
Kluczowe dla Szewczuka figury księgi, słowa, ogrodu i biblioteki stanowią bezpośrednie odnośniki do poetyki baroku, a będąc zakodowanym „tekstem barokowej kultury” są jednocześnie motywami najczęściej wykorzystywanymi przez twórców literatury postmodernistycznej. Wiadomo, jak wielką rolę odgrywa figura biblioteki w dziełach Borgesa, czy motyw księgi w twórczości Umberto Eco. Walerij Szewczuk sięga do tych samych symboli interpretując je zdaniem Horodniuk w sposób oryginalny, uwarunkowany w ogromnym stopniu symboliczno-filozoficznym kontekstem światopoglądowym ukraińskiego baroku i tradycji prawosławnej.

A więc biblioteka jako figura wszechświata, kultury, wiedzy; księga rozumiana jako „księga życia”, czy „księga świata” co implikuje interpretację życia w kategoriach narracji, opowieści; słowo (Logos), jako siła sprawcza, kreator historii tak jednostkowej jak i ogólnej, ogród jako zamknięta przestrzeń kultury, przeciwstawionej naturze. Wszystkie te symbole stanowią podstawę obrazowania postmodernistycznego a zarazem są figurami dobrze znanymi z literatury i sztuki XVII i XVIII-wiecznej. Analizując związki między poetyką baroku i postmodernizmu Horodniuk podkreśla liczne podobieństwa, zaznaczając, iż strategia obrazowania neobarokowego nieprzypadkowo stała się jedną z ulubionych form narracyjnych postmodernizmu, co wynika z podobieństwa światopoglądowego i zbieżności refleksji kulturowo-filozoficznej. [Городнюк 2006, 29]

Zarówno dla baroku jak i dla postmodernizmu obiektem badań i twórczych analiz staje się kultura, jako jedyna znacząca i sensowna rzeczywistość. Kultura jest jednak rozumiana w kategoriach symbolicznej konwencji, nie zaś rzeczywistości danej raz na zawsze. Podsumowując autorka stwierdza:

Невипадково однією з провідних стратегій літератури постмодерністської доби обирається необароко-стильова тенденція, що стверджує фрагментарність, динамізм, декоративність, внутрішню незавершеність. Необарокові прояви в культурі Нового та Новітнього часу стають знаками ревізії накопиченого досвіду, розмаїття культурних мов. Водночас постмодернізм має свої відповідники у добі Бароко на рівні світогляду і семіозису, що виявляється в інтерпретації таких категорій, як знак культури, текст культури, людина культури. [Городнюк 2006, 42]

Walerij Szewczuk, wykorzystując w swych utworach wymienione wyżej figury księgi, ogrodu, biblioteki i słowa, a także posługując się kategorią kultury peryferyjnej wpisuje się w kanon literatury ponowoczesnej, jednocześnie jednak - co wyraźnie podkreśla Horodniuk - zachowuje oryginalność, interpretując owe symbole $\mathrm{w}$ ramach tradycji rodzimej, inspirowanej kulturą grecko-bizantyjską. Posługując się kategorią słowa, jako Logosu autor 
odwołuje się do przejętej przez dawną Ruś tradycji bizantyjskiej, wprowadzając opozycyjną figurę słowa obcego (łacina) sugeruje iż synteza tradycji wschodu i zachodu stanowi o oryginalności ukraińskiej kultury. Podobnie, wykorzystując symbol księgi, autor interpretuje ją w kontekście staroruskiej tradycji opartej na Piśmie Świętym i odwołuje się do średniowiecznego rozumienia księgi jako rodzaju świętej ikony. Istotna dla twórczości Szewczuka figura ogrodu została wykorzystana zarówno jako parabola kultury przeciwstawionej naturze jak również w zaczerpniętych z tradycji staro ukraińskiej, kategoriach religijno-filozoficznych, przedstawiających ogród jako symbol ludzkiej duszy i Raju. Co istotne, symbole księgi, ogrodu, słowa i biblioteki nabierają w twórczości autora cech filozoficznych, wywodzących się z myśli Hryhorija Skoworody, co zasadniczo zmienia ich semantykę i sprawia, iż twórczość ukraińskiego pisarza nie tyle wpisuje się w kanon postmodernistycznego światopoglądu i obrazowania, co prezentuje własną, oryginalną interpretację symboli opartą na syntezie elementów zachodnioeuropejskich i wschodniosłowiańskich.

\section{Zakończenie}

W trzech przedstawionych $\mathrm{w}$ artykule monografiach analizujących prozę Wałerija Szewczuka wyraźnie widoczne jest rozumienie jego twórczości jako syntezy wpływów kultury zachodnioeuropejskiej (i amerykańskiej, w przypadku monografii Tarnaszyńskiej) z tradycją rodzimą, przynależącą jednoznacznie do wschodniosłowiańskiego kręgu kulturowego. W narracjach wszystkich trzech badaczek dostrzegam napięcie między wyraźnym dążeniem do wpisania prozy Szewczuka w kontekst filozoficzno-literackiej tradycji zachodniej (niekiedy wręcz w formie udowadniania „europejskości” ukraińskiej literatury) a naciskiem, kładzionym na oryginalność i „rodzimość” prozy ukraińskiego autora. Jak zaznaczyłam w pierwszej części tekstu, nie jest moim celem podważanie ustaleń analizowanych monografii, a jedynie próba spojrzenia na dyskurs literaturoznawczy jako na kolejną odsłonę rozumienia ukraińskiej kultury jako fenomenu „kultury pomiędzy”, o której wartości i oryginalności decyduje bezustanne dokonywanie twórczej syntezy wpływów, motywów, tradycji.

\section{Literatura}

Franczak J., 2002, Rzecz o nierzeczywistości. Mdłości Jeana Paula Sartre'a i Ferdydurke Witolda Gombrowicza, Kraków. 
Hnatiuk O., 2003, Pożegnanie z imperium. Ukraińskie dyskusje o tożsamości, Lublin.

Hrycak J., 2009, Nowa Ukraina. Nowe interpretacje, Wrocław.

Jakowenko N., 2010, Druga strona lustra. Z historii wyobrażen i idei na Ukrainie XVI-XVII wieku, Warszawa.

Riabczuk M., 2004, Dwie Ukrainy, Wrocław.

Szewczenko I., 1996, Ukraina między Wschodem a Zachodem, Warszawa.

Берегуляк А., 1993, Магічний реалізм та літературний міф-зиілення чи паначея у постколоніальному контексті? (Дім духів Ісабель Альєнде та Дім на горі Валерія Шевчука), „Сучасність” № 3, s. 67-75.

Білоцерківець Н., 1997, Інтелектуальні візерунки в дусі Умберто Еко, „Березіль” № 5/6, s. 188-189.

Блєдних Т., 1993, Історія в прозі Валерія Шевчука, „Слово і час” № 4, s. 52-57.

Горнятко-Шумилович А., 2001, Проза Валерія Шевчука традийійне $i$ новаторське, Szczecin.

Городнюк Н., 2006, Знаки необарокової культури Валерія Шевчука: компаративні аспекти, Київ.

Залеська-Онишкевич Л., 1996, Шлях вічного повороту (Птахи з невидимого острова Валерія Шевчука), „Сучасність” № 1, s. 93-96.

Сковорода Г., 2007, Вибрані твори, pod red. Л. Ушкалова, Харків.

Тарнашинська Л., 2001, Художня галактика Валерія Шевчука, Київ.

Чижевський Д., 1956, Історія української літератури. Від початків до доби реалізму, Нью-Йорк.

THE CONCEPT OF UKRAINIAN CULTURE "BETWEEN EAST AND WEST" IN MONOGRAPHS ON VALERIY SHEVCHUK'S PROSE

S U M M A R Y

In the article I analyze how the concept of "Ukraine between East and West" is reflected in the contemporary literary texts by an example of three monographs on Valery Shevchuk's prose. The authors of these monographs define Valeriy Shevchuk's prose as a synthesis of elements derived from the Ukrainian traditions and folklore, as well as from trends and tendencies of Western literature. 